\title{
Anchieta e os aspectos residuais do diabo medieval no Auto de Na Festa de São Lourenço
}

\author{
Francisco Wellington Rodrigues Lima ${ }^{1}$
}

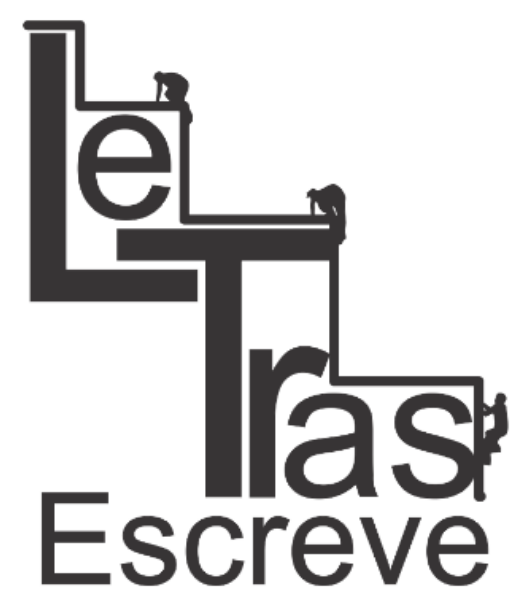

(ISSN 2238-8060)

Resumo: Figura emblemática presente no imaginário popular europeu, devido à ascensão do Cristianismo como religião dominante, o Diabo recebeu diversas definições e transformações que o moldaram através dos séculos. Na literatura dramática brasileira, em especial, no teatro quinhentista do Padre José de Anchieta, temos de maneira bem significativa a representação residual de tais representações do Diabo, seguindo os moldes do imaginário cristão medieval, adaptando-se, segundo as necessidades do padre jesuíta, à mentalidade do povo cristão que a qui se constituía, conforme se encontra no auto de Na Festa de São Lourenço. Sendo assim, o intuito deste trabalho é demonstrar os aspectos residuais da representação do Diabo medieval no teatro brasileiro quinhentista do Padre José de Anchieta, tendo como método de pesquisa, a Teoria da Residualidade Cultural e Literária, sistematizada por Roberto Pontes e o método comparativo.

Palavras-chave: Diabo, Medievo, Teatro, Residualidade.

Resumen: Figura emblemática en la imaginación popular europea debido a la subida del cristianismo como la religión dominante, el diablo recibió varios ajustes y transformaciones que han dado forma a lo largo de los siglos. La literatura dramática brasileña, especialmente en el teatro del siglo XVI del Padre José de Anchieta, que bien podría significativamente la representación residual de tales representaciones del diablo, siguiendo las líneas del cristiano medieval imaginario, la adaptación, según el sacerdote jesuita necesita, la mentalidad del pueblo cristiano que el chi se constituye, como se encuentra en uno mismo Na Festa de São Lourenço. Por lo tanto, el propósito de este trabajo es demostrar los aspectos residuales de la representación del diablo medieval en decimosexta teatro brasileño del Padre José de Anchieta, con el método de la investigación, la Teoría de la residualidad cultural y literaria, sistematizada por Roberto Pontes y el método comparativo.

Palabras-clave: diablo, Edad Media, Teatro, residualidad.

O teatro medieval trouxe à cena a representação do Diabo e a do Inferno. O Mal, através das artes cênicas, difundia-se com maior eficiência na mente do povo cristão e, cada vez mais, o pensamento católico cristão se firmava na sociedade medieval. As peças teatrais mostravam representações pavorosas e risíveis sobre a figura do Mal. No teatro vicentino, por exemplo, o Diabo representava,

1 Doutorando em Letras/Literatura da Universidade Federal do Ceará UFC. E-mail: wellrodrigues2012@yahoo.com.br 


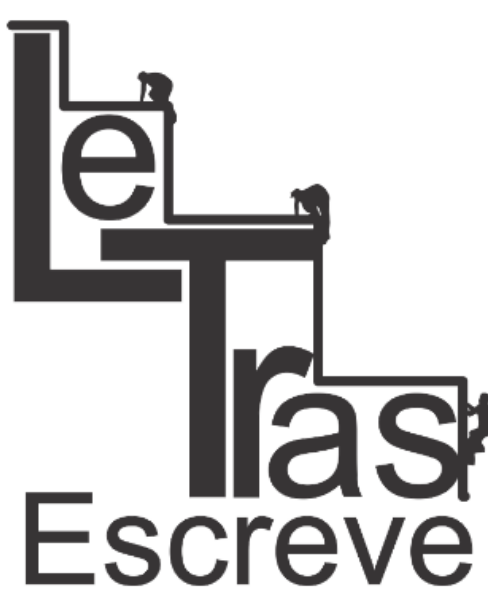

(ISSN 2238-8060) simbolicamente, papéis diversos: era juiz, acusador, relator dos pecados humanos, tentador, ludibriador etc; recebeu caracterizações e denominações, de acordo com o imaginário popular do período medieval, que o marcaram para sempre: Satã, Belial, Satanás, Lúcifer etc; tornou-se ridículo diante dos anjos e outros seres divinos; cômico quando se enredado por causa de sua tolice ou quando se colocava em situações de fracasso, derrota; é ainda causador do riso quando insultado, humilhado e enganado.

Foi esse pluralismo diabólico que se projetou na sociedade cristã medieval, através do teatro, que serviu de subsídios para o desenvolvimento desse artigo, uma vez que este transcorrerá em torno de uma das obras mais contundentes do Padre José de Anchieta: "Auto da Pregação Universal". Para tal, buscamos fundamentação teórica na Teoria da Residualidade Literária e Cultural, elaborada e sistematizada por Roberto Pontes, visando assim, entender a projeção residual do Diabo no teatro quinhentista brasileiro.

Roberto Pontes empregou o termo residualidade inicialmente em sua dissertação de mestrado, atualmente publicada em livro, cujo título é Poesia insubmissa afrobrasilusa (1999), tendo por objetivo demonstrar a presença de resquícios do passado que, ao longo do tempo, acumularam-se na mente humana e que são refletidos em textos de forma involuntária através de estruturas atualizadas ${ }^{2}$.

Os termos resíduo, residual e residualidade, na concepção de Roberto Pontes, têm sido empregados relativamente ao que resta ou remanesce na Física, na Química, na Medicina, na Hidrografia, na Geologia e em outras ciências, mas na Literatura (história, teoria,

${ }^{2}$ Hoje, a Teoria da Residualidade é registrada junto à Pró-Reitoria de Pesquisa e de Pós-Graduação da Universidade Federal do Ceará e ao Conselho Nacional de Pesquisa - CNPq -, e sua propagação pelo universo da pesquisa ganha, a cada dia, mais espaço e notoriedade entre alunos e professores pesquisadores do Programa de Pós-Graduação em Letras da Universidade Federal do Ceará e outras IES que reconhecem a importância do termo no estudo da tradição cultural e literária de nosso País.

https://periodicos.unifap.br/index.php/letras

Macapá, v. 6, n. I, Io semestre, 2016. 


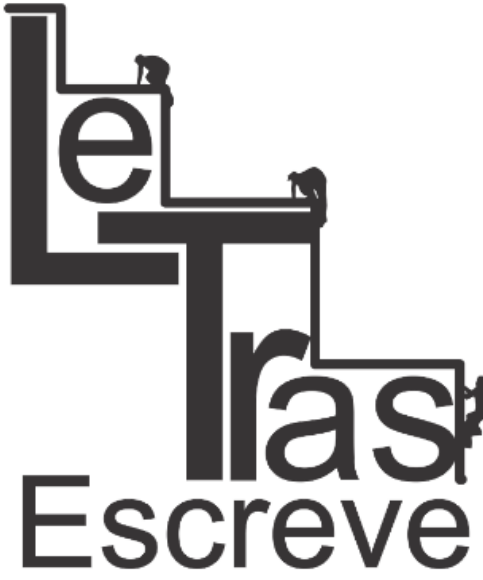

(ISSN 2238-8060)

critica e ensaística) quase não se tem feito uso dos mesmos (MARTINS, 2000, p. 264).

Segundo Roberto Pontes, resíduo é "aquilo que remanesce de uma época para outra e tem força de criar de novo toda uma obra, toda uma cultura" (PONTES, 2006, p. 01). Bem sabemos que na cultura do povo brasileiro, inclusive no período da colonização, muitos resquícios da época medieval cristalizaram-se como elementos vivos na mentalidade da sociedade que aqui se formava, substratos mentais, difundindo, inclusive, uma representação fértil do que remanesceu acerca do Diabo europeu, mesclando-se, engenhosamente, a cultura indígena cá existente, corpus central de nosso estudo, como bem representou Anchieta no Teatro Quinhentista Brasileiro. Ainda conforme Pontes, o resíduo "não é um cadáver da cultura grega ou da cultura medieval que deve ser reanimado nem venerado num culto obtuso de exaltação do antigo, do morto... não é isso... fica como material que tem vida" (PONTES, 2006, p. 02).

Seguindo as linhas mestras de Paulo Romualdo Hernandes (2008), Anchieta seria o santo que a Igreja Católica tanto necessitava. Considerado herói nacional, o jovem membro da Companhia de Jesus, segundo a concepção histórica da literatura, foi o "primeiro estrangeiro a escrever em brasileiro" (HERNANDES, 2008, p. 15).

Anchieta conviveu com múltiplas culturas (africana, européia, indígena) até os seus 14 anos. Quando chegou à Europa, ainda na juventude, entrou em contato com o período de maior efervescência das idéias humanistas. O convívio com professores humanistas o colocava diante de peças com temas bíblicos, realizadas nos pátios do Colégio das Artes, de peças com tradição estética inspirada em temas da tragédia e da comédia Greco-romana. Nessa mesma época, século XVI, Portugal vivia o período da Santa Inquisição e, os autos, como encenação dramática, se fortaleciam, trazendo elementos da tradição medieval para o teatro renascentista. Com 


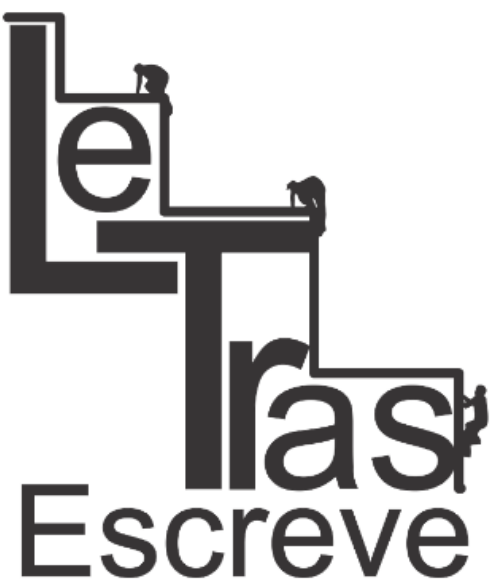

(ISSN 2238-8060)

efeito, segundo Eduardo Navarro (1999), naqueles anos, eram populares os autos de Gil Vicente, fato que nos revela, na obra de Anchieta, grande influência, seja no conteúdo, na forma ou no uso de alegorias e personagens.

Com a produção literária e dramatúrgica de Anchieta, inegavelmente, a história da vida cultural brasileira teve início. Seu interesse pelo nativo aparece não só como "objeto de especulação literária, mas também como condição de pessoa humana, como vínculo de cultura e, mais do que isso, como elemento de fixação de cultura" (FERNANDES, 1980, p. 45). Com o objetivo da evangelização, Anchieta soube explorar as manifestações indígenas, seus hábitos e crenças.

O auto de Na festa de São Lourençoé, segundo Eduardo Navarro, Décio de Almeida Prado e Padre Armando Cardoso, um dos mais conhecidos textos de Anchieta. A peça é constituída de cinco atos. No primeiro, deparamo-nos com o martírio de São Lourenço, morto no tempo de Valeriano, censor do Imperador romano Décio, por volta do ano 258 d.C. Ele fora acorrentado, açoitado, esfolado e posto sobre grelhas em cima de um braseiro. São Lourenço era diácomo do Papa Xisto II.

O segundo ato, conforme as pesquisas do Padre Aramando Cardoso é uma adaptação do segundo ato do Auto da Pregação Universal. Nele aparecem três diabos: Guaixará, Aimberê e Saravaia, desejosos em destruir a aldeia com suas maldades. Entretanto, três personagens surgem para por fim ao intento desses três diabos, livrando a aldeia indígena dos grandes males: São Lourenço, São Sebastião e o Anjo da Guarda. Esse segundo ato é rico de detalhes a respeito da cultura indígena da costa brasileira. Nele, vemos Guaixará ser recebido por uma velha índia que o pranteia em sua chegada, a saudação lacriminosa ${ }^{3}$. No entanto,

\footnotetext{
${ }^{3}$ Sobre este ritual indígena, ler a obra de Fernão Cardim. "Tratados da Terra e Gente do Brasil". Belo Horizonte: Editora Itatiaia; São Paulo: Editora da USP, 1980.
}

https://periodicos.unifap.br/index.php/letras Macapá, v. 6, n. I, Io semestre, 2016. 
leiamos primeiramente alguns trechos em que se vê a atuação e representação do Diabo:

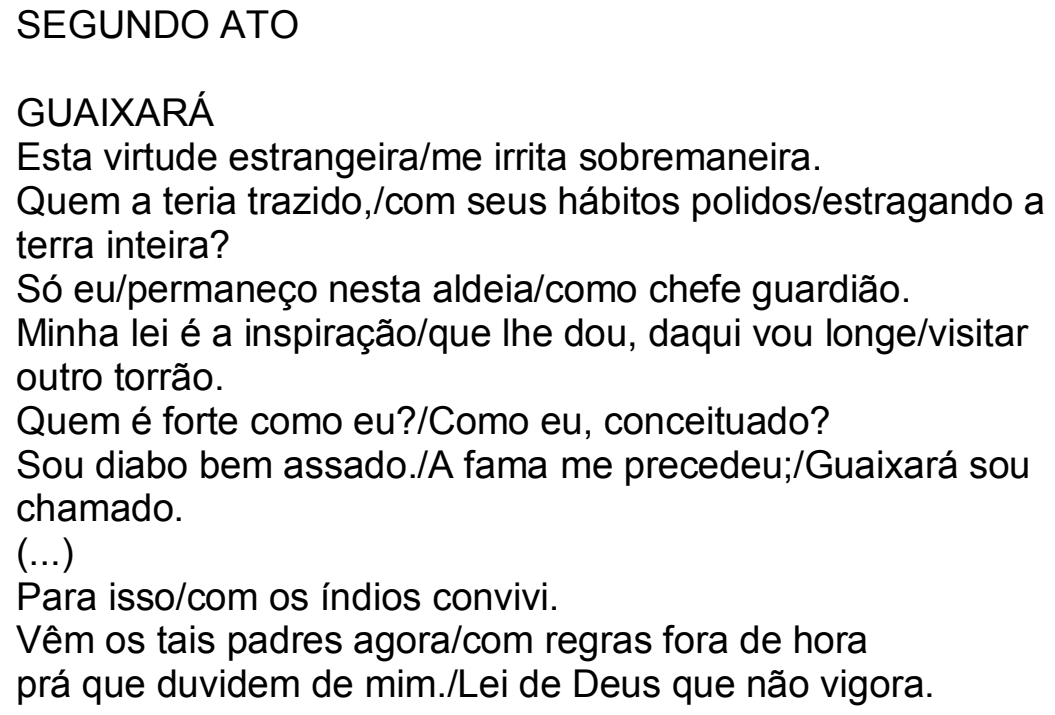

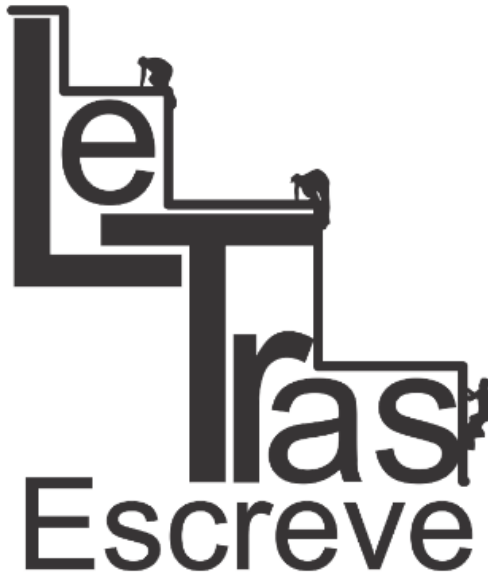

(ISSN 2238-8060)

Nesse trecho do auto anchietano, podemos observar, claramente, caracterizações do Diabo medieval adaptado pelo Padre José de Anchieta à crença popular que se enraizou no Nordeste do Brasil quinhentista, sendo representado como aquele que porta o Mal. O Diabo mostra-se irritado com os estrangeiros que trouxeram para cá "modos polidos" e a "Lei de Deus"; fala de sua grandeza, de sua fama; demonstra-se com soberba e arrogância; o que dita leis pecaminosas; o "diabo bem assado". Um ser acreditado, famoso, conceituado que tenta manter os costumes antigos - bebedeiras, matanças, amancebar-se, desonestidade, adúlterio ${ }^{4}$ - ameaçados pela ordem cristã. Leiamos o texto a seguir que complementa as colocações acima:

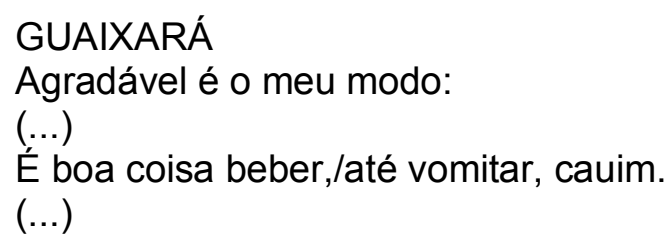

${ }^{4}$ Referente ao cauim, às festividades e rituais indígenas, ao adultério e outros costumes do índio brasileiro do século XVI, ler Hans Standen. "Duas Viagens ao Brasil". Trad.: Guiomar de Carvalho Franco. Belo Horizonte: Itatiaia, 2008 
É bom dançar, enfeitar-se/e tingir-se de vermelho;/de negro as pernas pintar-se,

fumar e todo emplumar-se,/e ser curandeiro velho.

Enraivar, andar matando/e comendo prisioneiros,/e viver se amancebando

e adultérios espiando,/não o deixem meus terreiros.

Vejamos agora outra passagem do segundo atona qual a velha nos lembra, num ritual de saudação lacriminosa, uma das mais conhecidas características do Diabo: o cheiro ruim de enxofre, que é um elemento residual do Diabo medieval na obra de Anchieta:

VELHA

O diabo mal cheiroso,/teu mau cheiro me enfastia.

Se vivesse o meu esposo,/meu pobre Piracaê,/isso agora eu Ihe diria.

Não prestas, és mau diabo./ (...)/(a velha foge)

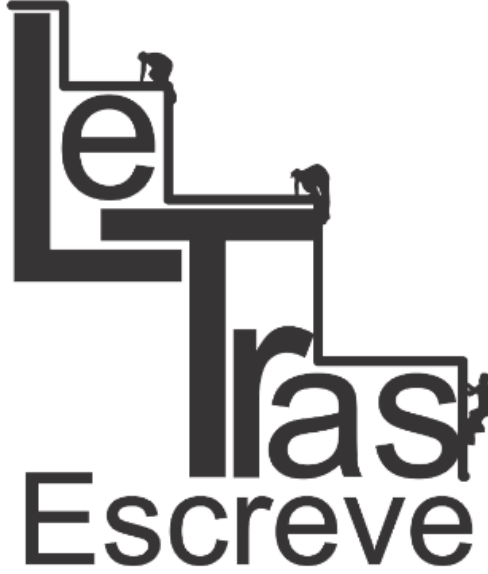

(ISSN 2238-8060)

Nos fragmentos a seguir, é interessante observarmos algo recorrente na maioria das peças anchietanas:o nome do Diabo aparece numa nomenclatura indígena (Guaixará), assim como seus demônios (Aimberê e Saravaia), de modo a retratar a adaptação ou atualização de termos portugueses à realidade brasileira. Esses seres, na verdade, representam chefes indígenas inimigos dos padres jesuítas e portugueses, bem como das tribos tupinambás e temiminós. Eduardo Navarro, na obra Teatro de José de Anchieta, afirma que os diabos desse auto tinham os mesmos nomes dos antigos chefes tamoios que lutaram na baía de Guanabara, mortos durante a guerra contra os franceses. Guaixará, segundo o autor, era um índio de Cabo Frio derrotado pelos soldados de Mem de Sá e por Araribóia em 1567 e, Aimberê, por sua vez, era um índio de Iperoig que tentou matar o missionário Anchieta quando este foi refém do índio em 1563. Saravaia era um espião francês que traiu os portugueses (NAVARRO, 1999, p. 9.). São bebedores de cauim, comedores de carne humana, desonestos etc. Vejamos: 
SÃO LOURENÇO

Quem és tu?

\section{GUAIXARÁ}

Guaixará, o ébrio./Sou o grão boicininga e jaguar./Como gente, sei brigar.

Voador, andirá-guaçu,/demônio que quer matar.

\section{SÃO LOURENÇO}

E esse, então?

\section{AIMBIRE}

Jibóia e socó,/sou o grão índio tamoio Aimbirê.

Sou sucuriju, gavião,/tamanduá feio, diabão,/luminoso como quê!

Esses diabos criados pelo padre são, como vimos acima, atualizações ligadas aos espíritos malignos que causavam medo e horror ao índio, transformando-os também em seres animalizados de espíritos infernais como os animais da fauna brasileira, boicininga, jaguar, jibóia, socó, sucuriju, gavião, tamanduá feio, concretizando, simbolicamente, os resíduos medievais do Diabo e de seus demônios na cultura do povo brasileiro, de acordo com a mentalidade da época. Segundo Paulo Romualdo Hernandes (2008, p. 41), são espíritos maus "encarnados em bestas da selva", das quais chegaram até nós descrições impressionantes. Guaixará e Aimberê se dizem anhangás e se descrevem ou se mostram como tal. Eis aqui algumas características zoomórficas híbridas importantes que reforçaram a representação do Diabo medieval sob a forma atualizada e cristalizada de animais selvagens e ferozes da fauna brasileira os quais circulavam pelas matas a perturbar os passantes. Essas características do Diabo assumindo forma animalesca, ainda conforme Hernandes (2008, p. 46), mesmo numa cultura ainda bem primitiva, conduzem-nos à criação de um bestiário, ou seja, seres "maravilhosos" que explicitam as formas medievais do mal num processo ao qual podemos chamar de hibridação Cultural que, com o passar do tempo, se enraizariam na mentalidade e na cultura popular brasileira. Assim nos diz Alfredo Bosi:

https://periodicos.unifap.br/index.php/letras Macapá, v. 6, n. I, Io semestre, 2016. 
Tudo quanto no reino animal metia medo ou dava nojo ao europeu vira signo dúbio de entidades funestas em ambos os planos, o natural e o sobrenatural. O mal se espalha nos matos ou se esconde nas furnas ou nos pântanos, de onde sai à noite as espécies da cobra e do rato, do morcego e da sanguessuga. Mas o perigo mortal se dá quando tais forças, ainda exteriores, penetram na alma dos homens. (BOSI, 1992, p. 74)

Sendo estes seres pertencentes ao folclore brasileiro, cujas descrições misturam crença religiosa e um olhar voltado para o zoomorfismo ou hibridismo medieval do Diabo adaptado às condições de "magia" e "encantamento" da mente da gente brasileira, vejamos algumas definições importantes sobre o Anhangá. Na visão de Câmara Cascudo:

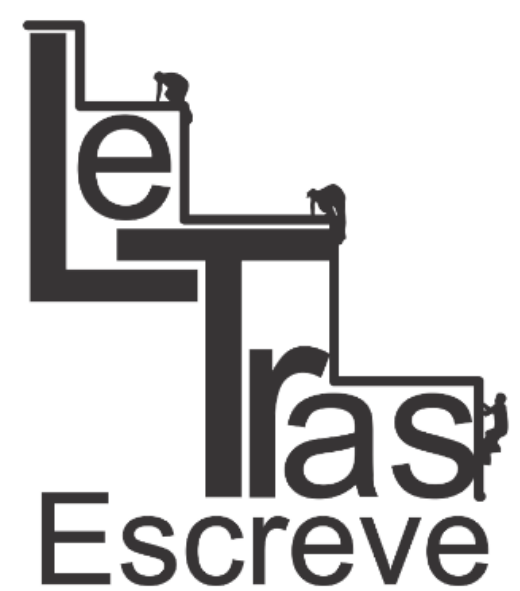

(ISSN 2238-8060)

Anhangá: espectro, fantasma, mito, visagem. Há, miraanhanga, tatu-anhanga, suaçu-anhanga, tapira-anhãnga, isto é, visagem de gente, de tatu, de veado e de boi. Em qualquer caso e qualquer que seja, visto, ouvido ou preseentido, o anhanga traz para aquele que o vê, ouve ou pressente certo prenúncio de desgraça, e os lugares que se conhecem como freqüentados por ele são mal-assombrados. O americanista e poeta Gonçalves Dias traduzia anhanga como contração de Mbai-aiba, a coisa má (Brasil e Oceania, 1867). Tastevin e Teodoro Sampaio, tupinólogos, traduziam por alma, espírito maligno, diabo, alma de finados (...). (CASCUDO, 2000, p. 16)

Para o Padre José de Anchieta,

Anhangá: é cousa sabida e pela boca de todos corre que há certos demônios, a que os Brasis chamam corupira, que acometem aos índios muitas vezes no mato, dão-lhes de açoites, machucam-nos e matam-nos. São testemunhas disto os nossos irmãos, que viram algumas vezes os mortos por eles. Por isso costumam os índios deixar em certo caminho, que por ásperas brenhas vai ter ao interior das terras, no cume da mais alta montanha, quando cá passam, penas de ave, abanadores, flechas e outras cousa semelhantes como uma espécie de oblação, rogando fervorosamente aos curupiras que não Ihes façam mal". (ANCHIETA, 1988, p. 138)

Marcgrave, na obra História Natural do Brasil, dá-nos a seguinte definição de Anhangá:

https://periodicos.unifap.br/index.php/letras

Macapá, v. 6, n. I, Io semestre, 2016. 
Crêem pela tradição dos antigos na imortalidade das almas, e as mulheres e fortes varões os quais trucidaram e comeram muitos inimigos, após a morte para os Campos Elísios, os quais julgam ser certos montes, ausentar-se e aí, dançar. Os restantes covardes e loucos que nada de digno fizeram, acreditam serem atormentados constumamente pelo Diabo após a morte. Chamam, porém o Diabo Anhanga, lurupari, Curupari, Taiguaiba, Temoti, Taubimama. (MARCGRAVE, 1942, p. 206)

Leiamos agora a seguinte passagem do auto de Na Festa de São Lourenço em que os Diabos Guaixará e Aimberé falam sobre a negação da existência de Deus e incita os indígenas ao pecado:

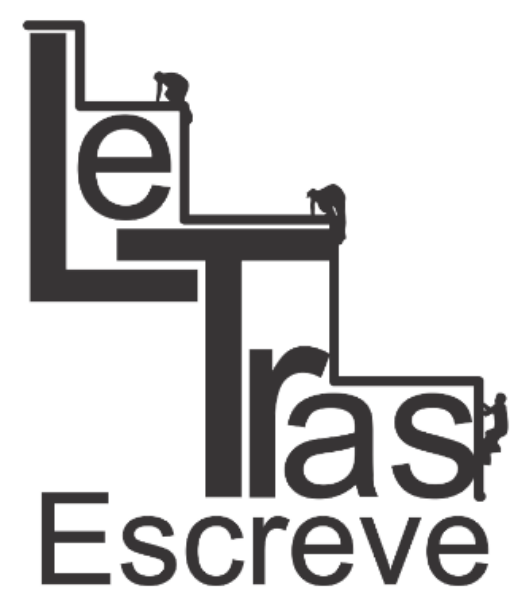

(ISSN 2238-8060)

\section{SEBASTIÃO}

Quem nalgum tempo ou idade/vos entregou essa gente para vossa propriedade?/Deus Senhor,/com santidade e amor, I alma e corpo lhes formou.

GUAIXARÁ

Deus?... É impossível... Porém/seus costumes não são bem/coisa lá pra que se diga...

é gente ruim:nega a Deus, peca e, por fim,/disso tudo ainda se gaba.

AIMBERÉ

Regorgita a igaçaba:as velhas tentam os seus/com cauim que não acaba.

A grande cabaça tolhe/a liberdade da mente;/em meio da dança quente,

nosso carinho os recolhe,/desprezando o Onipotente.

Conforme o trecho acima, o Diabo, com toda a sua soberba, coloca em questão a existência divina e os dogmas pregados pela Igreja Católica. Eletenta seduzir e conduzir o homem ao caminho do Mal; nega a existência de Deus e ressalta os pecados cometidos pelos índios. Nesse caso, a soberba do Diabo e a negação da existência de Deus caracterizam-se, mentalmente e culturalmente, como aspectosresiduaisdo Diabo medieval na obra de Anchieta: "É o Diabo Português, com os mesmos processos, seduções e pavores"(CASCUDO, 2000, p. 20). Vejamos este outro fragmento da obra do Padre José de Anchieta na qual se lê a queda do Diabo do Reino Celestial:

https://periodicos.unifap.br/index.php/letras

Macapá, v. 6, n. I, Io semestre, 2016. 
GUAIXARÁ

Quem há no mundo como eu?/Que ao próprio Deus desafia?

AIMBERÊ

Por isso Deus te abateu/e no inferno te meteu/que te abrasa noite e dia.

Nesse trecho, temos como resíduo do Diabo medieval e vicentino o episódio da queda de Lúcifer - o anjo de luz que, juntamente com outros anjos, tornou-se decaído, sendo este, confinado ao Inferno. Leiamos um trecho do Auto da Barca da Glória (VICENTE, 1958, p. 125) que ressalta o assunto:

IMPERADOR (ao Diabo)

O maldito querubin!/Ansi como descendiste/de Angel á beleguin,

querrias hacer á mi/lo que á ti mismo hiciete?

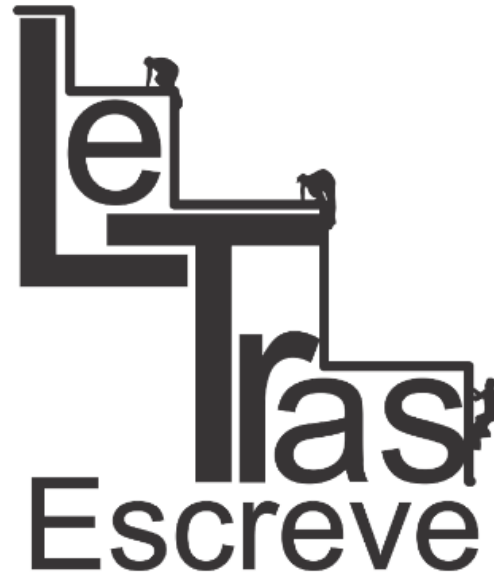

(ISSN 2238-8060)

O riso do Diabo também se faz presente nesse auto de Anchieta. O Diabo, segundo Padre Armando Cardoso, não é só malévolo, é frequentemente galhofeiro, fanfarrão e malicioso, semelhante à maneira como aparece em Gil Vicente. Era assim que esses personagens diabólicas agradavam o público da época. Eles tremiam na presença de Santos e Anjos, da Virgem, de Jesus Cristo e de Deus. Esse tremor de medo conduzia o público ao riso; a cena tinha um tom de comicidade. Os Diabos Guaixará e Aimberé eram ridiculardos conforme a presença das ações cômicas e das falas de tom jocoso das personagens. Nas passagens a seguir, podemos constatar o que se afirma:

\author{
AIMBERE \\ queimado? \\ SARAVAIA \\ Sim, ele! E o Bastião também. \\ AIMBERE \\ E esse outro que está ao lado? \\ SARAVAIA
}

Olha lá esse sujeito/que me está ameaçando!/Ai! O Lourenço

https://periodicos.unifap.br/index.php/letras

Macapá, v. 6, n. I, Io semestre, 2016. 
Será o Anjo encarregado/que esta aldeia em guarda tem?

Ai! Eles me esmagaraão!/É-me terrível mirá-los...

\section{GUAIXARÁ}

Sê forte, não fujas, não!/Vem, ataquemos então

para assim amendrotá-los./Das mãos flechas escapar!/Pois nos prostam destruídos.

\section{AIMBERE}

Olha, vem-nos açoitar:

Meus músculos vão ficar de tremor endurecidos.

(...)

\section{SEBASTIÃO}

Há aqui alguma rata,/ou repugnante gambá?/És noite talvez ingrata

que as galinhas desbarata/e ao índio empobrecerá?

(...)

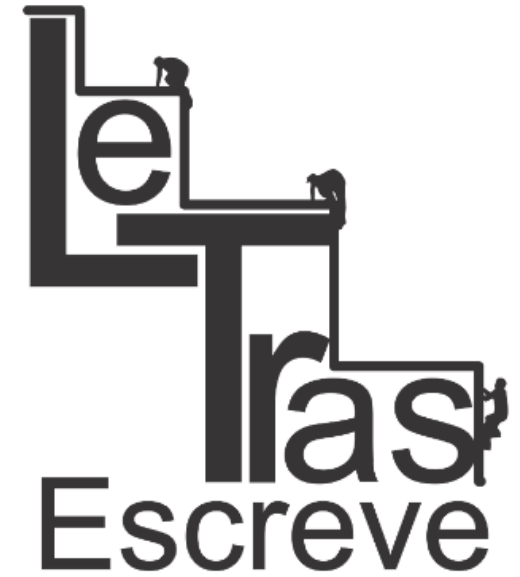

(ISSN 2238-8060)
ANJO

Que vossa terna maldita/no fogo pra sempre arda!

Temos todos esta dita,/pela bondade infinita:estarei sempre de guarda!

No Auto da Históriade Deus(VICENTE, 1958, p. 171), ri-se do Diabo, no momento em que Cristo aparece e o afugenta. Vejamos:

\section{BELIAL}

Senhor Lúcifer, eu ando doente,/treme-me a cara, e a barba também,

e dói-me a cabeça, que tal febre tem,/que soma Sam hetigo ordenadamente,

e doem-me as canelas:/sai-me quentura per entre as arnelas,

e segundo me acho, muito mal me sinto;/e algum gran desastre me pinta o destinto.

Até as minhas unhas estão amarelas,/que é gran labirinto.

(...)

\section{BELIAL}

Ergue-te, Senhor, que segundo creio,/pois que assi tremo e estou amarelo,

que será tomado esse nosso castelo,/e o gado que temos háde ser alheio.

\section{SATANÁS}

Isso é o que eu digo.

\section{BELIAL}

Rugem-me as tripas, arde-me o embigo,/e a boca empolada, assi como de figos.

Crede vós, Rei, que tendes inimigos;/porque estas doenças que trago comigo, 
denotam perigos.

O Diabo treme diante da face do bem. Ele fica amarelado perto dos Anjos e Santos, de Jesus Cristo, da Vigem e de Deus, provocando no público o riso. Essa reação também ocorre de maneira semelhante no trecho de Anchieta, no qual os diabos sentem medo das ameaças do Anjo e de São Sebastião; são chamados de ratos e gambás, têm medo dos açoites e não conseguem mirar os seres divinizados. Sendo assim, percebemos que o riso do Diabo é um elemento residual do período medieval e do teatro de Gil Vicente, que nos foi trazido das terras do além mar, e aqui no Nordeste do Brasil permaneceu representado e cristalizadoe atualizado no teatro de Anchieta.

O terceiro ato do Auto de Na Festa de São Lourenço é tão

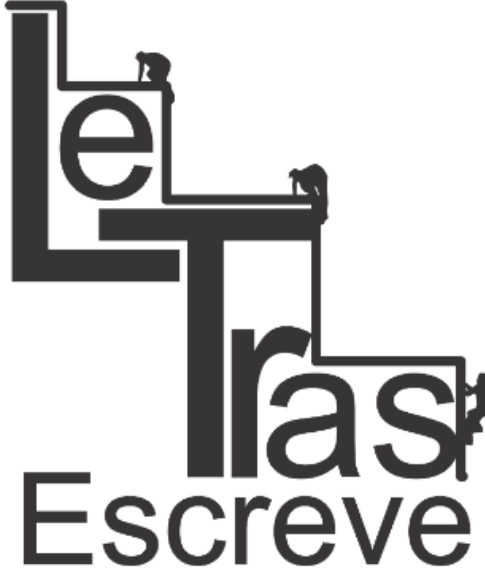

(ISSN 2238-8060) rico que, segundo os estudiosos da obra de Anchieta, merecia por si só ser tratado como núcleo diferente por valorizar toda a peça do padre missionário. A cena é constituída pelo castigo dos Imperadores Décio e Valeriano que martirizaram São Lourenço. $\mathrm{Na}$ cena, o Anjo convoca dois diabos ao palco, Amberê e Saravaia, e Ines ordena que arrastem para o Inferno os Imperadores pela maldade cometida contra o Mártir. Outros demônios aparecem na cena para dar cabo dos Imperadores, castigando-os com bastante crueldade. Vejamos os trechos que ilustram o assunto em questão:

ANJO

Aimberê,/ergue-te! Vem cá ao pé.

AIMBERÊ

Pronto, pronto! Em hora boa! / (Talvez mais prisão me dê Este pássaro-pessoa).

ANJO

Pra teu despojo imenso/ficam os imperadores/que mataram São Lourenço.

Queimem-se no fogo intenso,/em pena de seus horrores.

AIMBERE

Sim, com esses me contento:serão hoje meus cativos;/à força os levarei vivos,

https://periodicos.unifap.br/index.php/letras

Macapá, v. 6, n. I, Io semestre, 2016. 
num prazer bem odiento/para os fogos sempre ativos.

ANJO

Eia, depressa, a afogá-los!/Que não vejam mais o dia!

Eia, depressa, a atirá-los/ao fogo de vossos valos!/Reuni a companhia!

(...)

SARAVAIA

A quem vamos comer?

AIMBERE

Inimigos de São Lourenço.

AIMBERE

Vou comer seu coração.

$(\ldots)$

\section{TATAURANA}

Eis a muçurana inteira!/Eu comerei o que é braço,/Jaguaruçu o cachaço,

Urubu sua caveira/Caborê o seu pernaço.

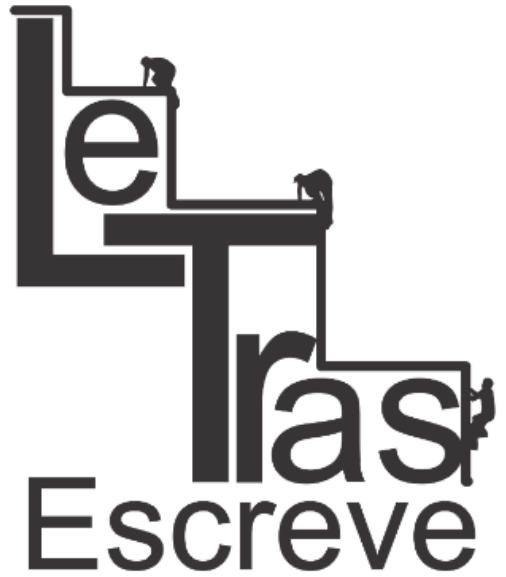

(ISSN 2238-8060)

\section{AIMBERE}

Sou mandado/por São Lourenço queimado/a levar-vos para casa

onde seja confirmado/vosso imperial estado,/em fogo que sempre abrasa.

Oh! Que tronos e que camas/já vos tenho aparelhadas,/nessas escuras moradas,

de vivas e eternas chamas,/sem nunca ser apagadas!

(..)

AIMBERE

(chamando os diabos)

Vindi aqui!/os malditos conduzi,/para o fogo queima-los; (...)

Nessa passagem do terceiro ato, o Diabo é representado como um servidor de Deus: "Pronto! Irei executar vossa lei"; como aquele que julga e condena ao mesmo tempo os Imperados pelo ato violento cometido contra o Mártir São Lourenço. Na cena, Anchieta utiliza-se dos costumes indígenas para a realização do castigo de Décio e Valeriano: o ritual indígena de sacrifício humano, seguido da Antropofagia (LÉRY, 1941).

Anchieta, nas falas de Décio e Valeriano, faz uma alusão ao Diabo e ao Inferno Pagão. Nesse momento da obra, citam-se os deuses mitológicos pagãos e o nome de Plutão, também conhecido

https://periodicos.unifap.br/index.php/letras

Macapá, v. 6, n. I, Io semestre, 2016. 
pelo povo grego como Hades, deus das terras infernais. Leiamos a seguinte passagem do texto:

\section{DÉCIO}

É nosso grão Deus e amigo/Júpiter, sumo senhor,/que recebeu grão sabor com o terrível castigo/e morte deste traidor.

(...)

Ai de mim! Este é Plutão/que vem de seu Aqueronte,/ardendo como tição, a levar-nos de roldão/ao fogo Flegetonte.

Outro fato também interessante nesse contexto é a referência que o padre missionário faz sobre Caronte e a altivez dos Imperadores perante a morte, o que nos remete a obra Diálogos dos Mortos, de Luciano de Samósata, e as barcas de Gil Vicente. Vejamosprimeiramente um trecho do Diálogos dos Mortos (1996) alusivo ao que se fala a título de ilustração:

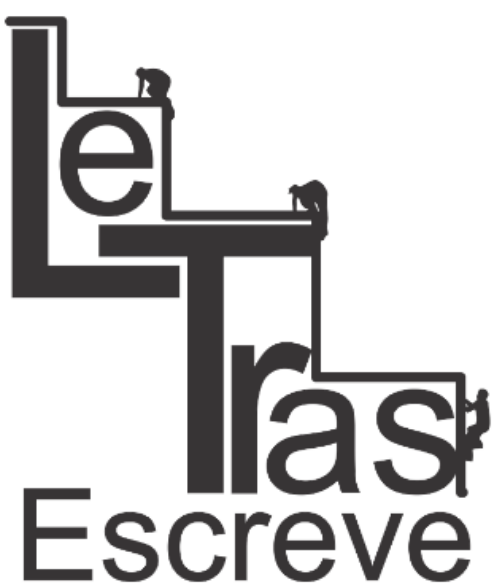

(ISSN 2238-8060)

\section{MINOS}

Hermes, esse bandido aí, o Sóstrato, seja lançado no Piriflégeton; que o sacrílego seja dilacerado pela Quimera e que o tirano seja estendido ao lado de Ticio para ter o fígado roído pelos abutres. E vocês, os bons, partam sem demora para os Campos Elísios e se instalem nas llhas dos BemAventurados, como prêmio pelas boas ações.

\section{SÓSTRATO}

Ouça, Minos, se não te parece justo o que eu vou dizer.

\section{MINOS}

Ouvi-lo outra vez, agora? Sóstrato, você não está convencido de que é um perverso e de que matou tanta gente?

SÓSTRATO

Estou, sim, mas veja se é justo que eu seja punido.

MINOS

$\mathrm{E}$ bem justo, se ao menos é justo que se pague por um erro.

Nesse momento, tomemos um fragmento do Auto da Barca da Glória (1958, p. 125) para constatar o que se afirma:

DIABO (ao Rei)

Señor, quiero caminar,/Nuesa Alteza há de partir. 
REI

Y por mar he de pasar?

\section{DIABO}

$\mathrm{Si}$, y aun tiene que sudar;/Ca no fue nada el morir.

Pasmareis: /Si mirais, dahi vereis/Adó sereis morador

Naquellos fuegos que veis;/Y llorando, cantareis/"nunca fue pena mayor"

Portanto, comparando os dois textos acima com o de Anchieta, é possível encontramos no auto de Na Festa de São Lourenço, resíduos do Diabo, não só medievais e vicentinos na obra anchietana, mas também resíduos do Diabo e do Inferno pagão que, de forma didático-teatral, cristalizaram-se e enraizaram-se na mentalidade do povo brasileiro do século XVI.

No quarto ato, aparece o anjo acompanhado de duas

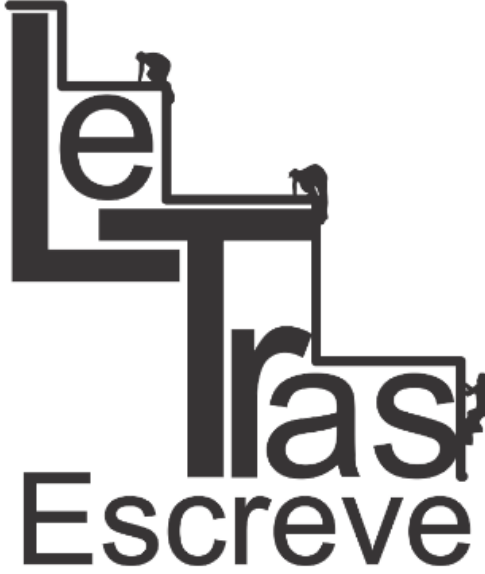

(ISSN 2238-8060) personagens alegóricas: o Temor de Deus e o Amor de Deus. Cada uma delas faz um sermão no qual busca apresentar uma reflexão sobre a vida humana e seu destino último. No quinto e último ato, deparamo-nos com uma dança de doze meninos em louvor a São Lourenço. Essa dança, segundo Eduardo Navarro, fazia parte de uma procissão de entronização da imagem do santo da igreja ou talvez fosse uma cerimônia levada a efeito após a representação do martírio.

Como podemos observar nesse nosso trajeto, os conhecimentos literários e culturais acerca do Diabo, com o passar do tempo, cristalizaram-se na mente do povo cristão durante a Idade Média com uma pluralidade de caracterizações e representações (substratos mentais) que se difundiram e migraram por diversas partes do mundo, portando consigo, traços remanescentes que se resinificaram na "sociedade brasileira" do século XVI através da via oral ou pela via escrita, num sentido espacial e temporal; traços residuais do Diabo que circularam por várias épocas e que chegaram até nós, em pleno século XXI. 


\section{Referências bibliográficas}

ANCHIETA, José de.Teatro de Anchieta: obras completas. Vol. III. Originais acompanhados de tradução versificada, introdução e notas pelo P. Armando Cardoso S.J. São Paulo: Edições Loyola, 1977. .Cartas, Informações, Fragmentos Históricos e Sermões.

São Paulo: Editora Itatiaia Limitada: Editora da Universidade de São Paulo, 1988.

BOSI, Alfredo. História concisa da Literatura Brasileira. 37. ed. São Paulo: Cultrix, 1999.

. Dialética da Colonização. 2 ed. São Paulo: Companhia das Letras, 1992.

CASCUDO, Luís da Câmara. Dicionário do Folclore Brasileiro. 9 ed., São Paulo, Global Editora, 2000.

CARDIM, Fernão. Tratados da Terra e Gente do Brasil. Belo Horizonte: Editora Itatiaia; São Paulo: Editora da USP, 1980.

FERNANDES, Francisco Assis Martins. A Comunicação na Pedagogia dos Jesuítas na Era Colonial. São Paulo: Edições Loyola, 1980.

HERNANDES, Paulo Romualdo. O Teatro de José de Anchieta Arte e Pedagogia no Brasil Colônia. São Paulo: Alínea Editora, 2008.

LÉRY, Jean de. Viagem à Terra do Brasil. Trad.: Sérgio Milliet. São Paulo: Livraria Martins, 1941.

LUCIANO. Diálogos dos Mortos. Tradução e notas de Maria Celeste Consolin Dezotti. Edição Bilíngüe. São Paulo: HUCITEC, 1996.

MACEDO, José Rivair. Riso, cultura e sociedade na ldade Média. Porto Alegre/São Paulo: Ed. Universidade/ UFRGS/ Editora Unesp, 2000.

MARCGRAVE, Jorge. História Nataural do Brasil. Trad.: Mons. Dr. José Procópio de Magalhães. Edição do Museu Paulista Comemorativo do Cinquotenário de Imprensa Oficial do Estado de São Paulo, 1942.

https://periodicos.unifap.br/index.php/letras Macapá, v. 6, n. I, Io semestre, 2016. 


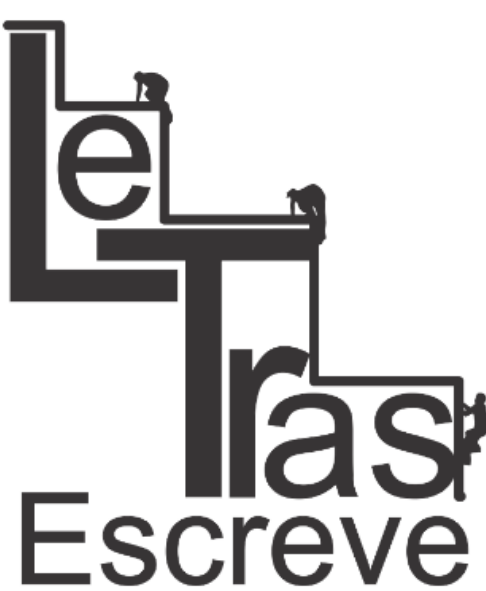

(ISSN 2238-8060)
MARTINS, Elizabeth. "O caráter afrobrasiluso, residual e medieval no Auto da Compadecida". In: SOARES, Maria Elias. ARAGÃO, Maria do Socorro Silva de. (Orgs) XVII Jornada de Estudos Lingüísticos. Anais. Fortaleza: Universidade Federal do Ceará UFC/Grupo de Estudos Lingüísticos do Nordeste - GELNE, 2000, V.II.p. 264.

NAVARRO, Eduardo de Almeida. José de Anchieta. São Paulo: Editora Martins Fontes, 1999.

PONTES, Roberto. Literatura insubmissa afrobrasilusa, Rio de Janeiro/Fortaleza, Oficina do Autor, EDUFC, 1999.

. Reflexões sobre a residualidade. Entrevista à Rubenita Alves Moreira. Comunicação na Jornada Literária "A residualidade ao alcance de todos". Departamento de Literatura da UFC, Fortaleza, julho de 2006.

PRADO, Décio de Almeida. Teatro de Anchieta a Alencar. São Paulo: Editora Perspectiva, 1993.

STANDEN, Hans. Duas Viagens ao Brasil. Trad.: Guiomar de Carvalho Franco. Belo Horizonte: Editora Itatiaia, 2008.

VICENTE, Gil. Obras Completas. Com prefácio e notas do Professor Marques Braga. Vol. II, 3 ed. Lisboa: Livraria Sá da Costa Editora, 1959.

Recebido em 02/02/2016. Aprovado em 20/03/2016. 